This item was submitted to Loughborough's Research Repository by the author.

Items in Figshare are protected by copyright, with all rights reserved, unless otherwise indicated.

\title{
Balancing London? A preliminary investigation of the "Core Cities" and "Northern Way" spatial policy initiatives using multi-city corporate and commercial law firms
}

\section{PLEASE CITE THE PUBLISHED VERSION}

http://dx.doi.org/10.1080/09654311003791325

\section{PUBLISHER}

Routledge (@ Taylor \& Francis)

\section{VERSION}

AM (Accepted Manuscript)

\section{LICENCE}

CC BY-NC-ND 4.0

\section{REPOSITORY RECORD}

Taylor, Peter J., Michael Hoyler, David M. Evans, and John Harrison. 2019. "Balancing London? A Preliminary Investigation of the "core Cities" and "northern Way" Spatial Policy Initiatives Using Multi-city Corporate and Commercial Law Firms". figshare. https://hdl.handle.net/2134/6517. 
This item was submitted to Loughborough's Institutional Repository (https://dspace.lboro.ac.uk/) by the author and is made available under the following Creative Commons Licence conditions.

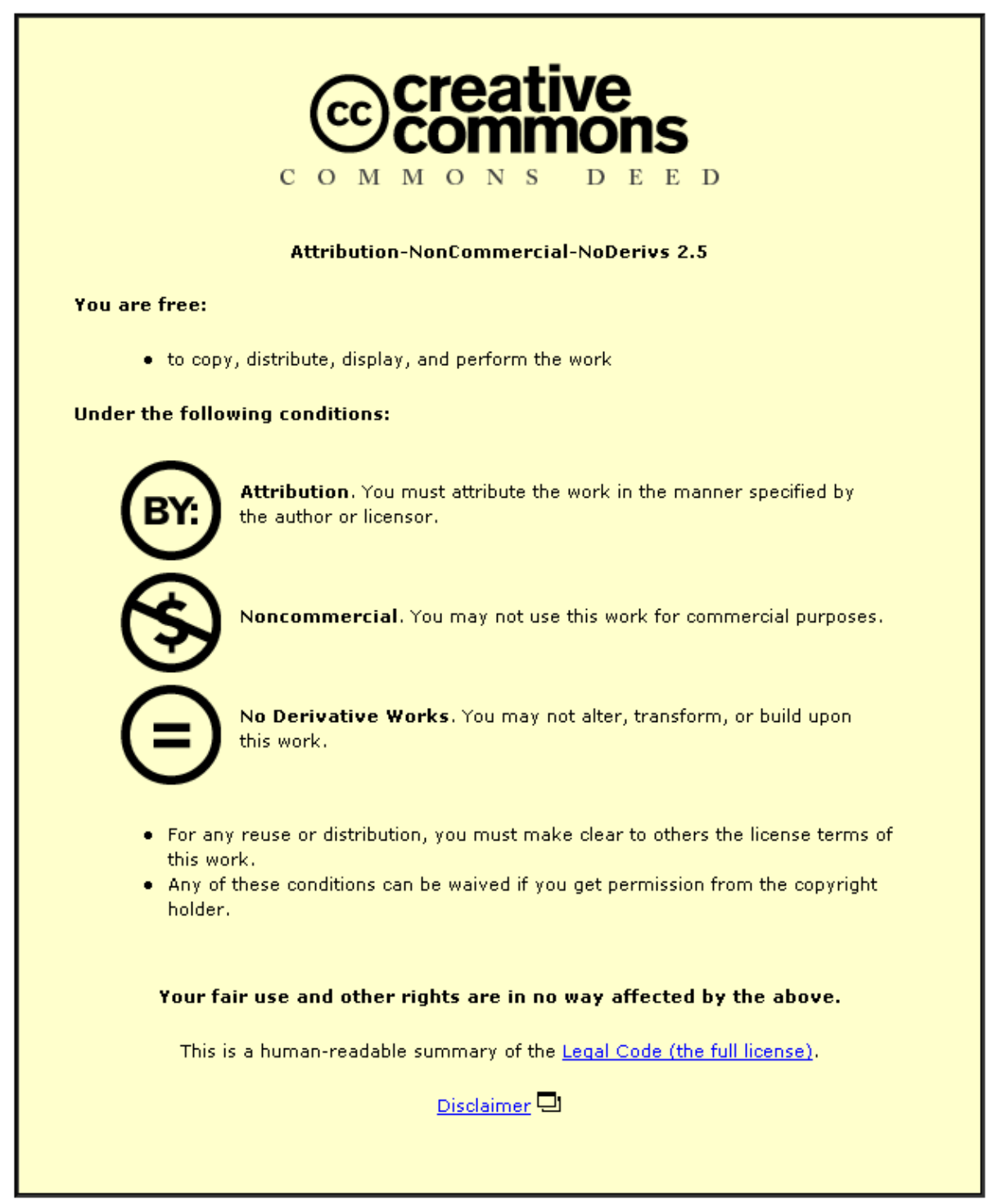

For the full text of this licence, please go to: http://creativecommons.org/licenses/by-nc-nd/2.5/ 


\title{
Balancing London? A preliminary investigation of the "Core Cities" and "Northern Way" spatial policy initiatives using multi- city corporate and commercial law firms
}

\author{
Peter J. Taylor, Michael Hoyler, David M. Evans and John Harrison \\ Department of Geography, Loughborough University \\ Loughborough LE11 3TU, UK
}

\begin{abstract}
This paper reports a preliminary investigation into the economic efficacy of two spatial frameworks - English Core Cities and the Northern Way - recently promoted by national policy makers. We ask whether they are consistent with contemporary economic process in the UK space economy through analyses of commercial multi-city law firms. The latter are treated as an 'indicator sector' to define the contemporary UK space economy as practised by law firms. Within this new space of flows, the location strategies of the law firms do confirm the salience of the Northern Way (as trans-Pennine corridor) and Core Cities as part of a larger UK metropolitan space of flows. Conflating the two spatial frameworks leads us to identify hints of a rebalancing of London within a metropolitan UK space. A Manchester polycentric mega-city region is found to be the likely candidate for this role. This finding in no way impinges on London's dominant global role and we conclude that perhaps mutuality between London and provincial cities is beginning to replace past negative dependency relations.
\end{abstract}


"London firms are ... under pressure from the increasingly impressive UK regionals. Since 2000, 20 non-London UK firms have entered the top 100, including firms based in Scotland, Bristol, Manchester, Liverpool, Newcastle, Cambridge, Nottingham, Birmingham, and Cardiff. A lower cost base is only part of the reason: these firms are ambitious, well managed, and have a clear idea of which direction they are going in."

(UK Overview: www.legal500.com, February 2007)

\section{Introduction}

London has long been considered an archetypal 'primate city', a city of such a size that it dominates its country. In the twentieth century this led to the political identification of primacy's corollary 'the regional problem' and the state's response with various regional policies (Massey, 1979). Whether there was any real expectation that these sticks (spatial regulation) and carrots (subsidies) would lead to a balancing of the primate behemoth, the policies most certainly did not create an economic counter-weight to London before the demise of such spatial planning in the 1980s. Interestingly, the early years of this century have produced evidence of a revival of the UK's provincial cities (Taylor \& Aranya, 2006). This paper further explores this possible change around in economic fortunes beyond London and the South East through providing new evidence that informs the credibility of two new spatial policies, the Core Cities programme and the Northern Way initiative. In both cases we do not interrogate the imputed content of the policies, rather we consider whether their spatial organization is conducive to playing an enabling role for supporting economic revival. Hence we test their respective spatial frameworks against the geography of contemporary economic processes. Past regional policies failed largely because they were working against the grain of economic change. Are current spatial policies more likely to be successful because they are working with the seeds of an actual economic revival? This is the question we explore here. 
To answer this question we must understand the broad economic-geographical processes that have created the spatial disparities that have concerned state planners. A good place to start is Doreen Massey's (1984) famous geology metaphor in which economic regional landscapes are interpreted in terms of layers of capital investment. Such an economic stratigraphy will show much investment for periods when a region is doing well and a dearth of investment for hard times. Thus the major northern cities of Britain were great Victorian metropolises that did indeed attract investment and even balanced the political and economic power of London for a short period (roughly from the 'Manchester School' of liberals to Birmingham tariff reformers). But this success was replaced by a paucity of new investments through the twentieth century, first in the more northerly regions and latterly in the Midlands leaving regional landscapes of 'old industry' as the outcome. In the meantime London has prospered throughout different investment cycles in a largely continuous generation of layers of 'new work' (Jacobs, 1969). No government sticks or carrots could appreciably affect these powerful processes from exacerbating imbalance in the UK spaceeconomy. But now these processes themselves have been disrupted by economic globalization. In one telling of this story (Castells, 1996), an industrial society is being replaced by informational society so that spaces of places (industrial regions) are being replaced as key economic arenas by spaces of flows (city networks). One outcome has been the creation of new 'global cities' that sit astride the world economy (Sassen, 1991/2001); London is now an archetypal global city (Taylor, 2005). Thus, initially, globalization was thought to favour just the largest metropolitan areas but there is now evidence that the new economic global processes are stimulating cities more widely than Sassen's narrow selection of global cities (Taylor \& Aranya, 2008). It is in this context that Britain's great Victorian cities may be making an economic revival; at last they appear to be putting an appreciable layer of new work on to their economic landscapes. 
Advanced producer services are highlighted by Sassen (1991/2001) as an important element of contemporary new work within cities. Traditionally just a single city would be the locale for professional service firms such as in advertising and commercial law but, under conditions of contemporary globalization, many service firms have sought to accommodate their increasingly global client list. This has meant opening new offices in cities across the world to provide 'local' services where and when needed (Taylor, 2004). The resulting world city network of 'global service centres' provides the professional infrastructure that enables economic globalization to proceed. London is a key node in this network but other UK cities are also beginning to be part of this global process; this was the essence of the evidence on global network connectivities reported by Taylor and Aranya (2006). In this paper we focus on links between UK cities and use legal services as the indicator. Law firms are the service sector classically linked to one city in which they nurture a clientele - we commonly identify firms by their city location, a Leeds law firm, an Edinburgh law firm, etc. - but many of the larger firms now have offices across two or more cities. It is these 'multi-city law firms' that are our subject matter here.

The use of law firms in this research is subtly different from Sassen's (1991/2001) treatment of advanced producer services where she emphasizes their practices in making global cities. Although important in the economic life of cities, on the whole law firms are relatively small economic players; we focus on them as indicators of economic vitality and change. This is to employ an ecological approach: just like a tawny owl might be used as an 'indicator species' for monitoring the health of a forest environment, so we use law firms as an 'indicator sector' to monitor the economic health of cities. The tawny owl is an indicator not because it is the dominant species but because it is at the heart of the intricate processes that sustain and reproduce a forest; this is analogous to commercial legal services necessarily at the centre of city-economic processes. If this usually conservative economic sector is converting to multi-city practice, it shows that economic spaces of flows are seriously impinging on legal practice 
markets. Resulting office networks themselves become components of the new spaces of flows that stimulated the economic growth in the first place. Thus the creation of networks of offices by commercial law firms indicates new investment to facilitate new work to cope with new demand for their services. Hence, a city with no multi-city law firms is interpreted as less integrated into new economic processes than a city housing numerous multi-city law firms. More generally, the pattern of multi-city law firms' office networks will indicate the economic space of flows in a space-economy. ${ }^{1}$ In this paper we describe the UK space economy as practised by leading commercial law firms which we use to inform current selected UK spatial policymaking.

The paper divides into six parts. We begin by describing the two spatial organizations featuring in the 'Core Cities' programme and the 'Northern Way' initiative. Our emphasis is on the spatial frameworks as spaces of flows rather than the administrative spaces of places of the policy makers. Second, the data we use are briefly described; 429 corporate and commercial law firms recommended by Legal 500 are reduced to a relevant sub-population of 135 multi-city law firms in the UK. Third, the UK space economy as practised by multi-city law firms is briefly described as the context for the spatial policy frameworks. In the fourth and fifth sections the Core City and Northern Way frameworks are assessed in terms of corporate law location practice. In the sixth section these findings are interpreted as metropolitan spatial strategies by

\footnotetext{
${ }^{1}$ Note that our method is to 'indicate' a space of flows. Directly measuring such flows for a large number of firms across a large number of cities would be an immense task relying on the cooperation of firms in what might be considered a commercially sensitive area. As is usual with such difficult measurement situations, we use indirect measurement; we find information that is readily available - office locations - and interpret these as 'office networks' in the sense of an enabling infrastructure for multi-office projects. In the case of service firms and their knowledge products, brand maintenance is vital and this is a key reason for expanding offices beyond the 'home city'. Keeping work 'in-house' means that there will be flows of information, knowledge, instruction, planning, advice, etc. between a firm's offices across cities. The office network reflects this space of flows and we use this to indicate potential flows between cities.
} 
commercial law firms. In a final discussion we conclude that there is some credible evidence for the balancing of London by a Manchester polycentric mega-city region within a metropolitan commercial legal practice.

\section{New spatial frameworks for national policy}

Law firms are our subjects, but understanding inter-city relations is the object of this study; we treat law firms as agents and relations between cities as outcomes and it is the latter that we compare to two current spatial policy frameworks. Both frameworks illustrate a shift in policy from 'spaces-of-places thinking' about territorial regions to a more city-centred approach derived from 'spaces-of-flows thinking' (Harrison, 2007). City policy has typically been at the scale of 'local policy' but the new relational thinking has created new multi-city policy. In addition, cities are not treated in simple competitive terms. Early policy initiatives based upon city competition (Oatley, 1998) were consistent with the city competition literature (Kresl, 1995; Lever \& Turok, 1999) but policy has become more sophisticated and mutuality between cities, networks of cities, is now recognised as relevant to policy (e.g. van den Berg et al., 2007). This theoretical and practical move towards 'bringing cities together' is specifically the case with the two spatial policy frameworks studied here; explicitly in the Core Cities programme, and integral to the Northern Way as trans-Pennine corridor.

\section{The Core Cities}

The Core Cities group, a strategic alliance of England's major regional cities outside London, was formed in the mid-1990s by Birmingham, Bristol, Leeds, Liverpool, Manchester, Newcastle and Sheffield to enhance the position of England's provincial centres both nationally and internationally. The group was joined in 2001 by Nottingham in a move to incorporate the East Midlands, the 
only region outside South East and East of England previously not represented in the Core Cities group. Underlying this government-backed initiative in urban networking and lobbying was the recognition that English regional cities lacked in economic vitality and competitiveness compared to their European counterparts, a view supported in a series of commissioned comparative studies (CURDS, 1999; Parkinson et al., 2004; Robson et al., 2000; see also Wood, 2006a, 2006b). This posed a problem, as strong regional cities had come to be seen as potentially "add[ing] more cylinders to the UK's economic engine" while at the same time "provid[ing] more space for London to further develop its unique global city role" (ODPM, 2003a, 1). The rationale behind the new Core City initiative was therefore not redistribution of wealth from the South East to other regions but an overall strengthening of the national economy through city-led growth outside of London and the South East. Core Cities were to provide the leadership through which lagging regions could fulfil their economic potential, both through cooperation within their individual city-regions and through collaboration with other major regional cities: Inter-city cooperation lies at the heart of the Core Cities agenda to create competitive English regions.

\section{The Northern Way}

Launched against the backdrop of the government's Sustainable Communities Plan (ODPM, 2003b), the Northern Way programme challenged the three northern Regional Development Agencies - One North East, Northwest Development Agency and Yorkshire Forward - to outline how the North could unlock the potential for faster economic growth to act as a counterweight to the London economy (Goodchild \& Hickman, 2006). Originally designed around two growth corridors - a primary growth corridor running from Liverpool in the west, through Manchester, Leeds, and Sheffield to Hull in the east, and a secondary growth corridor running from Newcastle in the north, to Sheffield in the south Making it Happen: The Northern Way promoted "greater inter-regional 
collaboration" to "boost connectivity...so that the sum of activity is greater than the parts" (ODPM, 2004, foreword).

As consultation and thinking developed around this strategy, it became evident that the challenge facing the northern RDA taskforce - how to unlock the potential for faster economic growth in the north - was very similar to the concerns of the Core Cities group. This recognition of a shared agenda led the RDAs and the Core Cities group to combine their efforts to re-launch the Northern Way in September 2004. Despite only six months elapsing since the launch of the first strategy, this second strategy Moving Forward: The Northern Way (NWSG, 2004) reinforced the importance of cooperation and connectivity between nodal regional cities within the Northern Way growth strategy by emphasising the importance of city-regions within the two growth corridors. As well as identifying five city-regions centred on the five core cities in the north of England - Leeds, Liverpool, Manchester, Newcastle and Sheffield - the recognition of a further three city-regions - Central Lancashire, Hull \& Humber Ports and Tees Valley - can be seen as a clear indicator of the importance being placed upon connectivity and cooperation between cities and city-regions in the economic development of northern England.

As such, both these spatial frameworks may be interpreted as new policy thinking to bring cities beyond London into Castells' (1996) socio-spatial framework he calls 'network society'. But are these spatial planning initiatives congruent with actual new economic processes?

\section{Data collection}

Our data source is The Legal 500 survey of UK law firms. It is intended as a guide for customers of legal services but in the process it has created an indispensable set of data for analysis of law firms in the UK. Assessments of law 
firms in 2006 were based upon in-depth interviews with over 3,000 clients as well as questionnaires sent out to law practices. Combined with the on-going research of the Legal 500 team, the results are both quantitative (rankings of firms) and qualitative (summaries of firm's work) (Freeland \& Kelly, 2006). We have used their website (www.legal500.com) and have focused upon the regional breakdown of firms they recommend. Specifically we have used their lists of 'corporate and commercial law firms'2 from each region and nation of the UK.

There are 429 such law firms identified by Legal 500 in February $2007^{3}$ and these constitute our initial population. They are broken down into several categories in Figure 1. The following categories are eliminated for the purposes of this study:

- 152 firms with offices in just one city (usually one office only)

- 60 firms in London that have foreign offices but no other UK offices

- 82 firms with local office networks only

The remaining 135 firms are multi-city corporate and commercial law firms (MCLFs) and are the sub-population that is analysed below. ${ }^{4}$

\footnotetext{
${ }^{2}$ Unlike at the global level (Taylor, 2004), at the national scale it is necessary to restrict choice in this way in order to ensure the focus is upon law as an advanced producer service and thereby eliminating non-commercial consumer services (Sassen, 1991/2001).

3 These are derived from the 'overview' lists for the 10 English regions and Scotland, Wales and Northern Ireland. In addition, firms listed under Corporate and Commercial subheadings for Corporate Tax (all except Northern Ireland) and for EU and Competition (all except East Midlands, Wales and Northern Ireland) are included. London is treated as a separate entity by Legal 500; as well as firms listed in the 'overview', we include all firms under Corporate and Commercial subheadings: Corporate tax, Customs \& Excise, EU and competition, Financial services, Flotations: small and mid-cap, Mergers and acquisitions, M\&A: smaller deals, M\&A: US law capability, Partnership, Private equity, VAT and indirect tax, and Venture capital.

${ }^{4} 73$ of these firms have at least one office in London, 62 do not have a London office.
} 


\section{The UK space economy as practised by MCLFs}

Before we focus on the two spatial frameworks that are our subject, it is necessary to paint the larger picture of the UK space economy as context. In fact what we will be looking for in terms of the Core Cities and Northern Way is whether their 'spaces' can be identified as denser patches of network in the overall pattern of MCLF office geographies.

In Figure 2, the frequency distribution of locations that have two or more MCLFs is shown (London is omitted because it is exceptional in having far more firms than any other UK city; and the many locations with just one MCLF are omitted as not being of 'national' interest for our purposes here). The resulting distribution is bimodal and, even with the omission of London, there is a very uneven tail. For some of the analyses below we will refer to the top 26 cities in this distribution, those housing 4 or more MCLFs. ${ }^{5}$

Our prime interest is not simply the number of firms in a city but rather the way in which multi-city firms provide connections between cities. This is to study not cities per se, but city dyads in terms of how many firms they share. Figure 3 shows the distribution of all dyads sharing more than three MCLFs (again the large numbers at the lower end of the distribution, sharing just one or two firms, are omitted as not relevant to this study). This indicates another very uneven tail with, this time, a definite break in the distribution separating the top 18 dyads above 5. These dyads are shown in Figure 4. This diagram represents the UK space economy as practised by MCLFs in terms of a city-centred 'space of flows'. Clearly the London dominance is shown but the largest link is EdinburghGlasgow. Overall the key message of this figure is the fact that there is a UK-

5 The cities are: 73 MCLFs - London; 25 - Edinburgh; 23 - Manchester; 21 Birmingham; 19 - Glasgow; 16 - Leeds; 11 - Bristol; 9 - Cardiff, Milton Keynes; 8 - Reading; 7 - Aberdeen, Leicester, Liverpool, Nottingham, Oxford, Southampton; 6 - Cambridge, Newcastle, Northampton, Norwich, Sheffield; 5 Derby, Exeter; 4 - Belfast, Guildford, Plymouth. 
wide pattern of inter-city relations that encompasses cities beyond London and the 'greater South East'. Even with just these top 18 dyads there is a real sense of a vibrant economy centred on cities outside London.

\section{The Core Cities}

The Core Cities feature prominently in Figure 4 and this is elaborated in Figure 5 where all Core City dyad links are mapped. This shows the importance of Manchester and Birmingham with links to all other Core Cities; between them they feature as part of every larger link. Newcastle, Sheffield and especially Nottingham feature as the least connected Core Cities.

Clearly the English Core Cities are important in the UK space economy but do they represent a specific dense patch in the overall space of flows? Table 1 shows that this is indeed the case. In the second column their rankings in the top 26 cities from Figure 2 in terms of numbers of MCLFs are shown: they split into 2 groups with four cities highly ranked (Manchester, Birmingham, Leeds and Bristol) and four quite middling (Liverpool, Sheffield, Nottingham and Newcastle). However, as the dyad analysis has implied, it is not simply the location of an office that is important but how that office is part of a larger network is more relevant. This is shown in the next two columns that look at the number of links each Core City has to the other 25 top cities. In this case no Core City decreases in ranking and six climb higher in the rankings. In the final two columns the number of links to other top 25 cities are shown as a ratio of the number of MCLFs (column 2). In this case all but one Core City increases its ranking relative to the MCLFs ranking. Overall this means that MCLFs using Core Cities for doing their business tend to have larger networks of offices than other leading cities in England, Scotland, Wales and Northern Ireland. In other words, Core Cities do define a denser patch in the UK space economy as practised by MCLFs. 


\section{The Northern Way}

Five of the eight Core Cities are in the three Northern English regions; is there a specific connectivity between them as the Northern Way initiative proposes? Table 2 shows this not to be the case across the whole swathe of the 'North'. Of the 35 MCLFs with offices in the North, only two have offices in all three regions. In contrast, the highest frequency in Table 2 is for MCLFs with offices in both the North West and Yorkshire/Humberside. These eleven are far more numerous than for MCLFs with offices in just any one region. This suggests there may be some salience to the Northern Way but only in its trans-Pennine formulation.

This latter suggestion is confirmed in Figure 6 where all MCLF dyads in the North are shown. Clearly there is an especially dense patch of network from LiverpoolPreston-Chester to Leeds-Sheffield centred on Manchester. This is very much a curtailed trans-Pennine corridor with no links across to Hull. In fact, in terms of incipient city-regions in the Northern Way initiative, the latter is conspicuous by its absence and contrasts with Central Lancashire with numerous links around Preston. The other incipient city-region, Tees Valley does appear to feature south of Newcastle but without any centre in itself. Instead, Newcastle dominates but the city is only weakly linked the rest of the North as Table 2 has already shown. As such, the putative Newcastle-Sheffield corridor is not at all apparent in MCLF practice.

Thus the Northern Way initiative spatial frameworks are only partially expressed in MCLF practice. But what has been found appears very cohesive and important: a trans-Pennine corridor with Liverpool city-region and an incipient Central Lancashire city-region in the west, a Leeds city-region and Sheffield cityregion in the east, and with Manchester right at the centre. 


\section{A metropolitan UK interpretation}

Let us return to the subjects in our study: the MCLFs. Of course, when law firms are making investment decisions to extend their office network they will not be using the spatial planning concepts that have been our object of concern. These agents of change are searching out investment opportunities that match the changing needs of their clientele. This is why we have studied them and matched their practice to the two spatial policy approaches of Core Cities and Northern Way. But, as previously noted, these two spatial planning initiatives greatly overlap: the majority of Core Cities are in the Northern Way proposals and even our limited trans-Pennine corridor encompasses half the Core Cities. Thus, we might subsume the trans-Pennine region into the Core City network but, more importantly, the latter can be subsumed into a general metropolitan UK network. In hindsight, this is what Figure 2 was showing us. Our conjecture is that this is the likely way in which the major MCLFs view the UK space economy.

To evaluate this idea, UK metropolitan cities have been defined as London, plus Core Cities, plus Belfast, Cardiff, Edinburgh and Glasgow. For each of the 135 MCLFs the numbers of offices they have in these metropolitan cities have been counted. Taking the remainder of a firm's offices from this number gives a metropolitan score; all 135 scores define an index of metropolitan strategy. These scores are arrayed in Figure 7, which shows a tri-modal frequency distribution. Each mode is used to define the categories non-metropolitan, hybrid and metropolitan. For the latter we can identify 'ultra-metropolitan' MCLFs as those in the tail beyond the metropolitan mode in Figure 7. There are 18 such firms and they are listed in Table 3.

It is these 18 law firms with their ultra-metropolitan spatial strategies whose practices are mainly responsible for the UK space economy as we have portrayed it in this paper. As can be seen from Table 3, London dominates with all but one of the firms having an office in London. But note also the relative 
importance of the Core Cities compared to the other cities considered in the table. Consisting of twice as many cities as the non-English metropolitan cities, they have nearly three times the number of these firms' offices. The comparison with other cities as identified from Figure 2 is even more emphatic: Core Cities are less than half the number of these 'other cities' but have over five times the number of ultra-metropolitan firms' city offices. It is apparent that English Core Cities are central to metropolitan strategies in making the UK space economy through the practice of MCLFs.

Finally the last column in Table 3 is important. In Figure 1 we eliminated the multi-city law firms that had foreign offices plus a London office. Obviously this reflects the globalization processes that have made London a global city, equal in status with New York as the leading city for trans-jurisdictional law in the world. Although this is the major legal gateway between the UK space economy and the world economy (Beaverstock et al., 1999; Morgan \& Quack, 2005), there are MCLFs in UK provincial cities that have foreign offices; eight are shown in Table 3. These are dominated by DLA Piper with 51 foreign offices that, combined with the UK offices, encompass 3,200 lawyers in 24 countries (DLA Piper website). But Pinsent Masons, Hammonds and Eversheds also have sizeable networks beyond the UK. This does not mean that any UK city can rival London as a global law city, of course, but these foreign offices do provide the potential for bypassing London on occasion; UK cities are being brought into the process of commercial law globalization.

\section{Discussion}

And so back to where we began: is there evidence that the UK provincial city revival could be beginning to redress an unbalanced space economy centred on London? Our results are perhaps surprising and definitely intriguing. We have provided evidence to support the efficacy of both spatial frameworks tested but, 
more importantly, our results show that the two spatial frameworks are not to be considered as alternative policy initiatives. Rather they are complementary; nurturing the trans-Pennine corridor is to facilitate the growth of a network concentration - the Manchester polycentric mega-city region - within a UK metropolitan spatial framework (Figure 8).

This network concentration is not a rival UK core to London; it is important not to lapse back into a competitive cities mode of thinking. The Manchester polycentric mega-city region will not be competing with London in any feasible future scenario of economic globalization. What we are suggesting here is a tendency towards a rebalancing of the UK space economy. What may be happening is that the current round of growth in London has produced a global city within an emerging network or informational society that is quite different from earlier cycles of economic expansion in the twentieth century. In the latter economic processes, London's growth often appeared as detrimental to other UK cities (Taylor, 1997); it could be interpreted as the malignant projection of a city's economic power so well described by Jacobs (1984). But expression of a city's power does not have to have a negative dependency effect on its neighbours; Jacobs (1984) also shows how cities can have large regional effects that stimulate economic expansion. In the twenty first century there are a few signs, such as the evidence presented above, that indicate London's relations with other UK cities might be turning around into a positive influence. The current layer of London's economic landscape features successful adaption to economic globalization and in this non-national context other UK cities might just be finding new niches alongside London, using this global city for their own purposes and advantage. 


\section{References}

Beaverstock, J. V., Smith, R. G. \& Taylor, P. J. (1999) The long arm of the law: London's law firms in a globalizing world economy, Environment and Planning $A$, 31(10), pp. 1857-1876.

Castells, M. (1996) The Rise of the Network Society (Oxford: Blackwell).

CURDS (1999) Core Cities: Key Centres for Regeneration: Final Report (Newcastle: Centre for Urban and Regional Development Studies).

Freeland, R. \& Kelly, D. (2006) Introduction, in The Legal 500 (19th edition) (London : Legalease) http://www.legal500.com/1500/intro06.pdf

Goodchild, B. \& Hickman, P. (2006) Towards a regional strategy for the north of England? An assessment of 'The Northern Way'. Regional Studies, 40(1), pp. 121-133.

Harrison, J. (2007) From competitive regions to competitive city-regions: a new orthodoxy, but some old mistakes. Journal of Economic Geography, 7(3), pp. 311-332.

Jacobs, J. (1969) The Economy of Cities (New York: Random House).

Jacobs, J. (1984) Cities and the Wealth of Nations (New York: Random House).

Kresl, P. K. (1995) The determinants of urban competitiveness: a survey, in P. K. Kresl \& G. Gappert (Eds) North American Cities and the Global Economy, pp. 45-68 (Thousand Oaks, CA: Sage). 
Lever, W. F. \& Turok, I. (1999) Competitive cities: introduction to the review. Urban Studies, 36(5/6), pp. 791-793.

Massey, D. (1979) In what sense a regional problem? Regional Studies, 13(2), pp. 233-243.

Massey, D. (1984) Spatial Divisions of Labour (London: Macmillan).

Morgan, G. \& Quack, S. (2005) Institutional legacies and firm dynamics: the growth and internationalization of UK and German law firms, Organization Studies 26(12), pp. 1765-1785.

NWSG (2004) Moving Forward: The Northern Way - First Growth Strategy Report (Newcastle: Northern Way Steering Group).

Oatley, N. (1998) Cities, Economic Competition and Urban Policy (London: PCP).

ODPM (2003a) Cities, Regions and Competitiveness: Second Report from the Working Group of Government Departments, the Core Cities, the Regional Development Agencies (London: Office of the Deputy Prime Minister).

ODPM (2003b) Sustainable Communities: Building for the Future (London: Office of the Deputy Prime Minister).

ODPM (2004) Making it Happen: The Northern Way (London: Office of the Deputy Prime Minister).

Parkinson, M., Hutchins, M., Simmie, J., Clark, G. \& Verdonk, H. (2004) Competitive European Cities: Where Do the Core Cities Stand? (London: Office of the Deputy Prime Minister). 
Robson, B., Parkinson, M., Boddy, M. \& Maclennan, D. (2000) The State of English Cities (London: DETR).

Sassen, S. (1991/2001) The Global City (Princeton, NJ: Princeton University Press).

Taylor, P. J. (1997) Is the United Kingdom big enough for both London and England? Environment and Planning A, 29(5), pp. 766-770.

Taylor, P. J. (2004) World City Network: A Global Urban Analysis (London: Routledge).

Taylor, P. J. (2005) Leading world cities: empirical evaluations of urban nodes in multiple networks, Urban Studies, 42(9), pp. 1593-1608.

Taylor, P. J. \& Aranya, R. (2006) Connectivity and city revival, Town \& Country Planning, 75(11), pp. 309-314.

Taylor, P. J. \& Aranya, R. (2008) A global 'urban roller coaster'? Connectivity changes in the world city network, 2000-04, Regional Studies, 42(1), pp. 1-16.

van den Berg, L., Braun, E. \& van der Meer, J. (Eds) (2007) National Policy Responses to Urban Challenges in Europe (Aldershot: Ashgate).

Wood, P. (2006a) Urban revival and knowledge-intensive services: the case of the English 'Core Cities', in J. W. Harrington \& P. W. Daniels (Eds) KnowledgeBased Services, Internationalization and Regional Development, pp. 233-262 (Aldershot: Ashgate). 
Wood, P. (2006b) Urban development and knowledge-intensive business services: too many unanswered questions? Growth and Change, 37(3), pp. 335361. 
Table $1 \quad$ Core Cities in a UK legal space of flows

\begin{tabular}{|l|c|c|c|c|c|c|}
\hline \multirow{2}{*}{ Core Cities } & \multicolumn{3}{|c|}{ MCLFs } & \multicolumn{2}{c|}{$\begin{array}{c}\text { Links to other top 25 } \\
\text { cities }\end{array}$} & \multicolumn{2}{c|}{$\begin{array}{c}\text { Top 25 links per } \\
\text { MCLF }\end{array}$} \\
\cline { 2 - 7 } & Number & Rank & Number & Rank & Ratio & Rank \\
\hline & & & & & & \\
Birmingham & 21 & 4 & 67 & 2 & 3.19 & 2 \\
Bristol & 11 & 7 & 54 & 4 & 4.91 & 1 \\
Leeds & 16 & 6 & 50 & 6 & 3.13 & 3 \\
Liverpool & 7 & $11=$ & 19 & 9 & 2.71 & 6 \\
Manchester & 23 & 3 & 66 & 3 & 2.87 & 5 \\
Newcastle & 6 & $17=$ & 14 & 16 & 2.33 & 11 \\
Nottingham & 7 & $11=$ & 18 & 10 & 2.57 & 8 \\
Sheffield & 6 & $17=$ & 15 & 14 & 2.50 & 10 \\
& & & & & & \\
\hline
\end{tabular}


Table 2 Basic regional geography of multi-office law firms with at least one office in the North

\begin{tabular}{|l|c|}
\hline \multicolumn{1}{|c|}{ Regional pattern of law firms' office networks } & $\begin{array}{c}\text { Number of } \\
\text { firms }\end{array}$ \\
\hline Offices in all three regions & 2 \\
Offices in North West and Yorkshire/Humberside & 11 \\
Offices in North East and Yorkshire/Humberside & 1 \\
Offices in North East and North West & 0 \\
Offices in North West & 6 \\
Offices in Yorkshire/Humberside & 4 \\
Offices in North East & 3 \\
All other offices outside the North & 8 \\
\hline
\end{tabular}


Table 3 Metropolitan strategy law firms in metropolitan cities

\begin{tabular}{|c|l|c|c|c|c|c|}
\hline $\begin{array}{c}\text { Metro. } \\
\text { score }\end{array}$ & \multicolumn{1}{|c|}{$\begin{array}{c}\text { Ultra-metropolitan } \\
\text { strategy firms }\end{array}$} & London & $\begin{array}{c}\text { Core } \\
\text { cities }\end{array}$ & $\begin{array}{c}\text { Other } \\
\text { metro } \\
\text { cities }\end{array}$ & $\begin{array}{c}\text { Other } \\
\text { cities* }\end{array}$ & $\begin{array}{c}\text { Foreign } \\
\text { offices }\end{array}$ \\
\hline 8 & DLA Piper & 1 & 5 & 2 & 0 & 51 \\
7 & Pinsent Masons & 1 & 4 & 2 & 0 & 6 \\
5 & Irwin Mitchell & 1 & 5 & 0 & 1 & 2 \\
4 & Beachcroft LLP & 1 & 4 & 0 & 1 & 1 \\
4 & Halliwells LLP & 1 & 3 & 0 & 0 & 0 \\
4 & Hammonds & 1 & 3 & 0 & 0 & 12 \\
3 & Addleshaw Goddard & 1 & 2 & 0 & 0 & 0 \\
3 & Bevan Brittan LLP & 1 & 2 & 0 & 0 & 0 \\
3 & Bircham Dyson Bell & 1 & 0 & 2 & 0 & 1 \\
3 & Browne Jacobson LLP & 1 & 2 & 0 & 0 & 0 \\
3 & Cobbetts & 0 & 3 & 0 & 0 & 0 \\
3 & Dundas \& Wilson CS & 1 & 0 & 2 & 0 & 0 \\
3 & Eversheds LLP & 1 & 4 & 1 & 3 & 6 \\
3 & HBJ Gateley Wareing & 1 & 2 & 2 & 1 & 0 \\
3 & McClure Naismith & 1 & 0 & 2 & 0 & 0 \\
3 & McGrigors & 1 & 0 & 3 & 1 & 1 \\
3 & RadcliffeLeBrasseur & 1 & 1 & 1 & 0 & 0 \\
3 & Weightmans & 1 & 3 & 0 & 1 & 0 \\
\hline \multicolumn{2}{|l}{} & 17 & 43 & 16 & 8 & 80 \\
& & & & & & \\
\hline
\end{tabular}

*These are the remaining cities in the top 26 listed in note 5. 
Figure 1 Identification of multi-city corporate and commercial law firms (MCLFs) in the UK

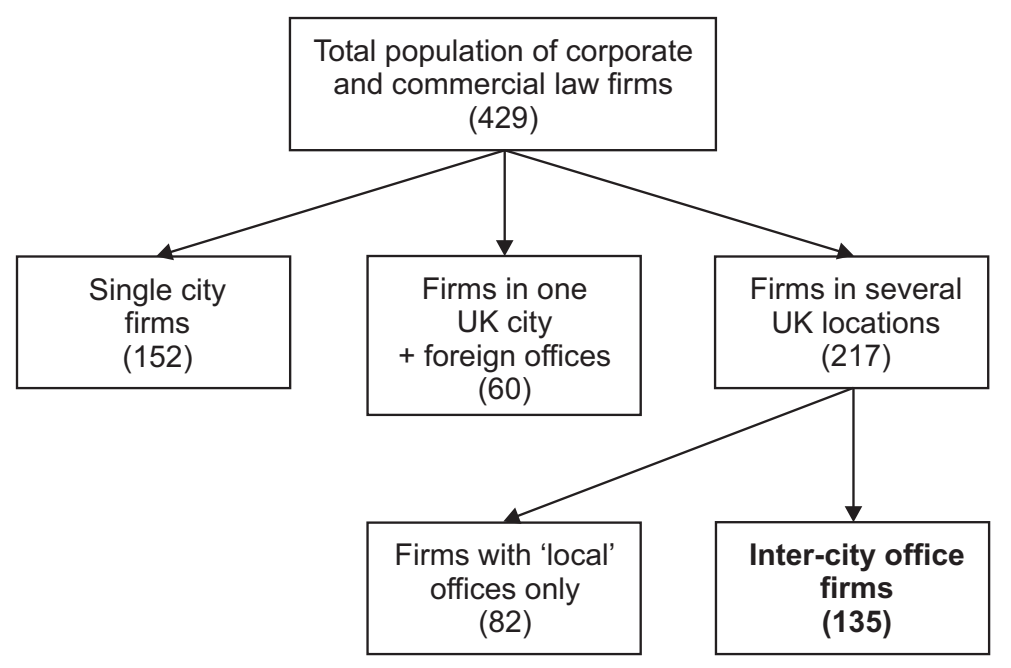




\section{Figure 2 MCLFs in cities}

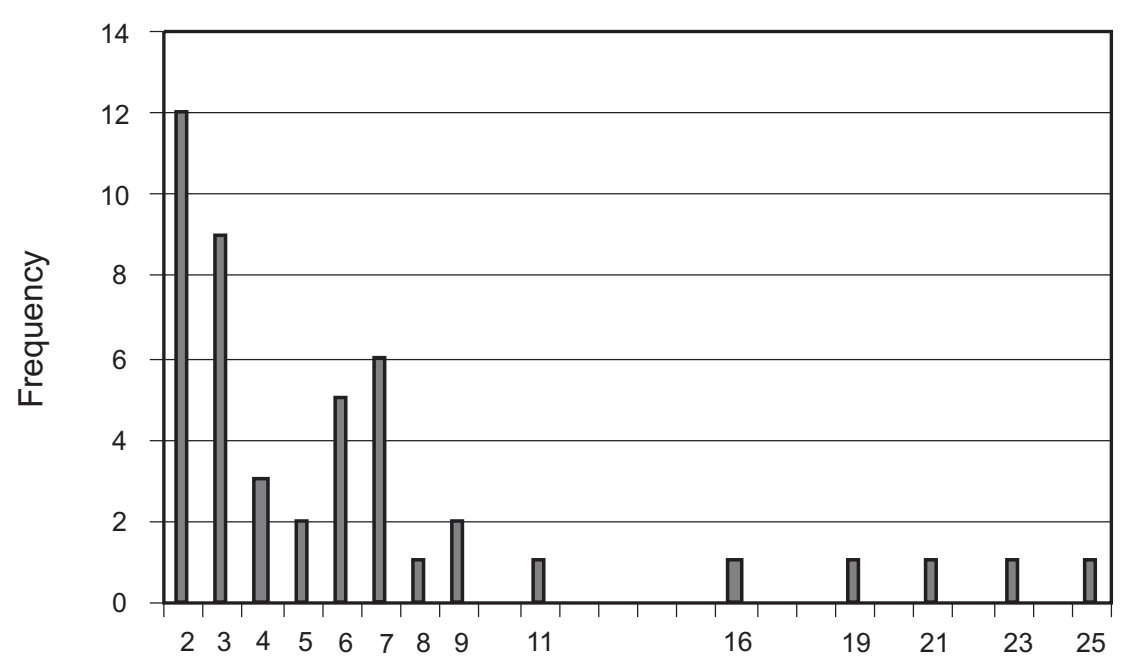

Number of MCLFs

Figure $3 \quad$ City dyads

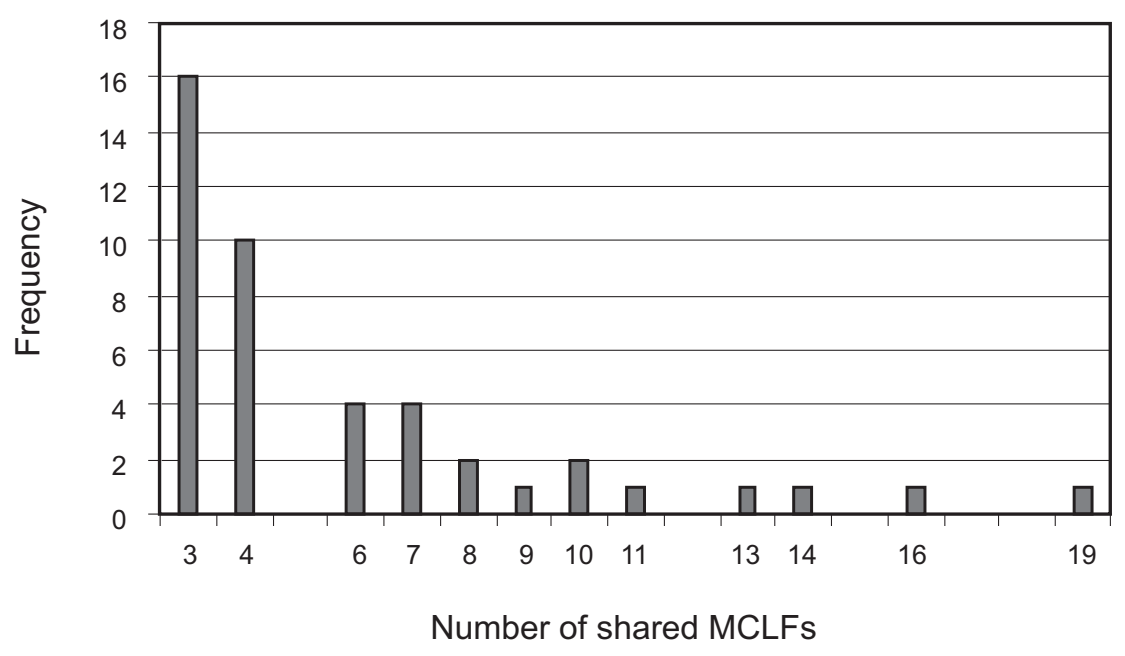


Figure 4 The UK space economy as practised by MCLFs

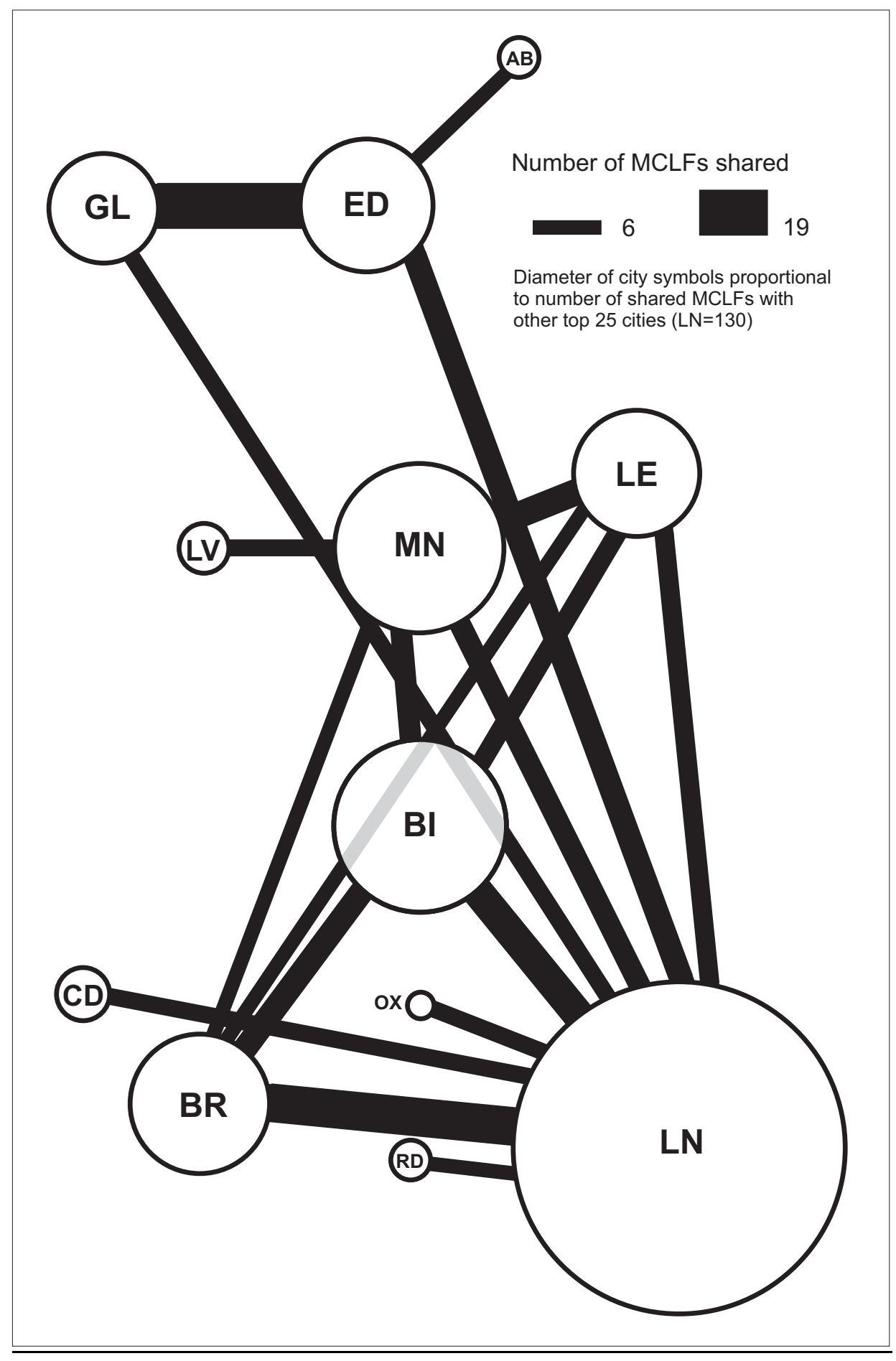

City codes: AB Aberdeen, BI Birmingham, BR Bristol, CD Cardiff, ED Edinburgh, GL Glasgow, LE Leeds, LN London, LV Liverpool, MN Manchester, OX Oxford, RD Reading 
Figure $5 \quad$ Inter-city links of MCLFs in Core Cities

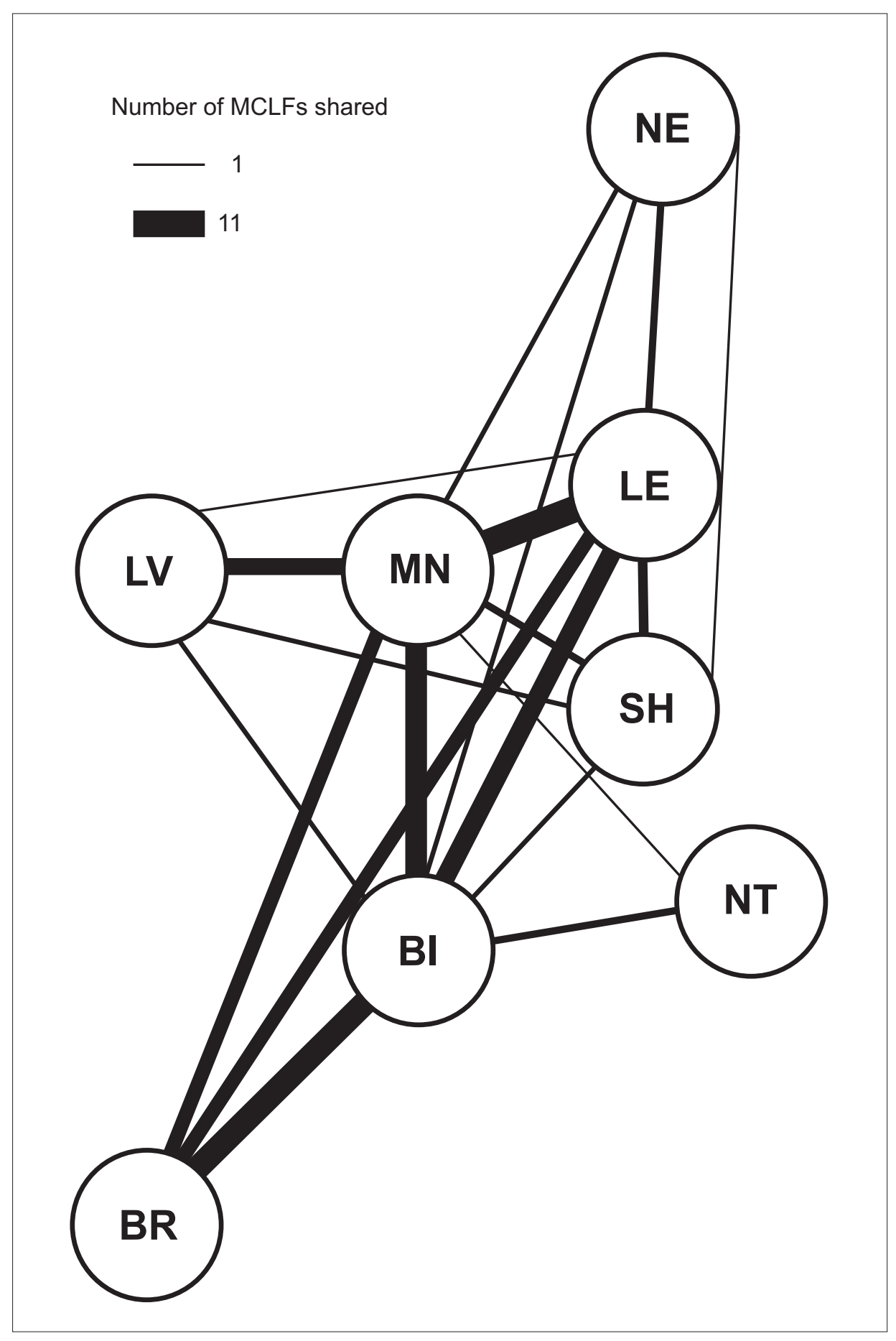

City codes: BI Birmingham, BR Bristol, LE Leeds, LV Liverpool, MN Manchester, NC Newcastle, NT Nottingham, SH Sheffield 
Figure $6 \quad$ Inter-city links of MCLFs in the North

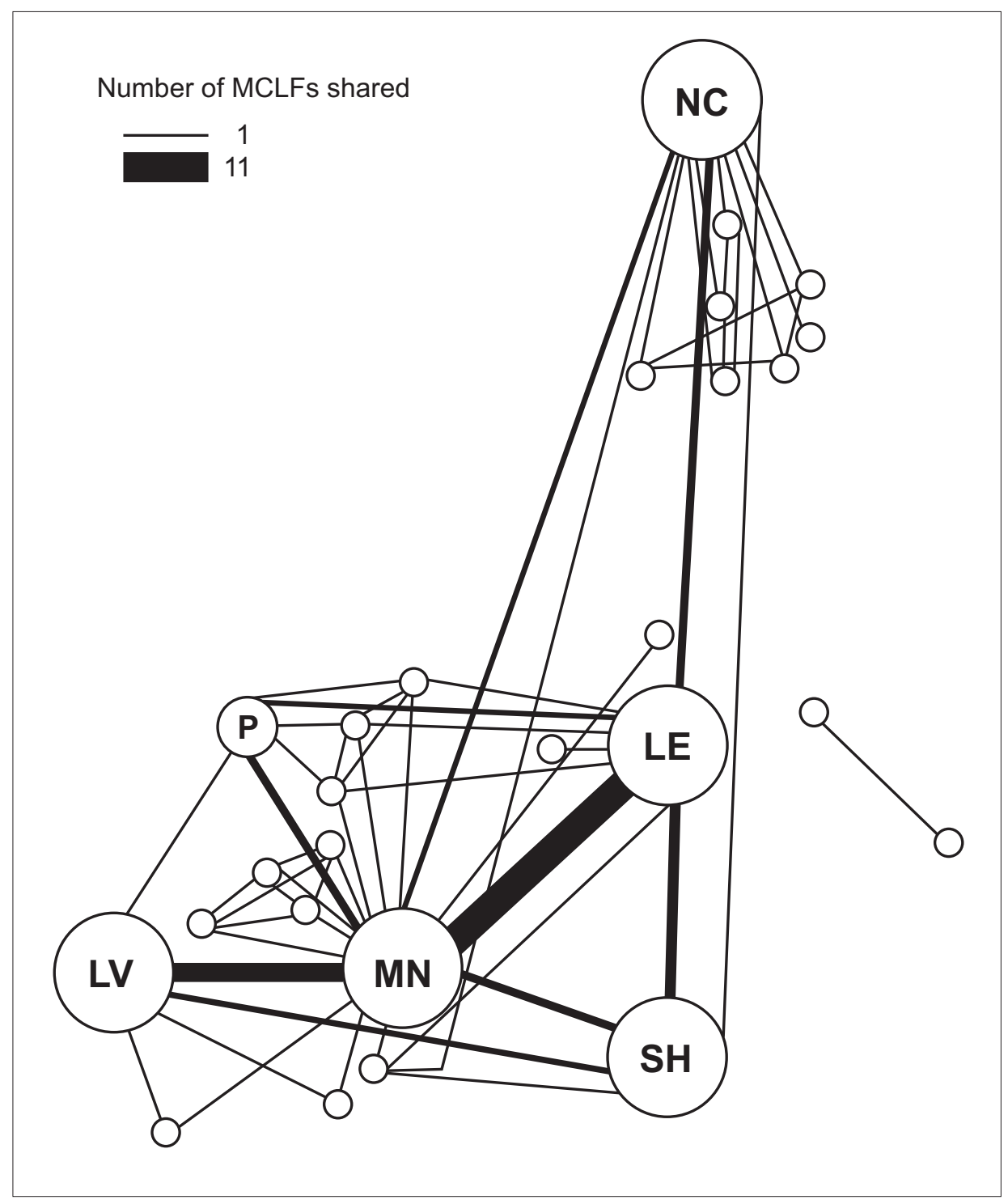

City codes: LE Leeds, LV Liverpool, MN Manchester, NC Newcastle, P Preston, SH Sheffield 


\section{Figure $7 \quad$ Metropolitan scores}

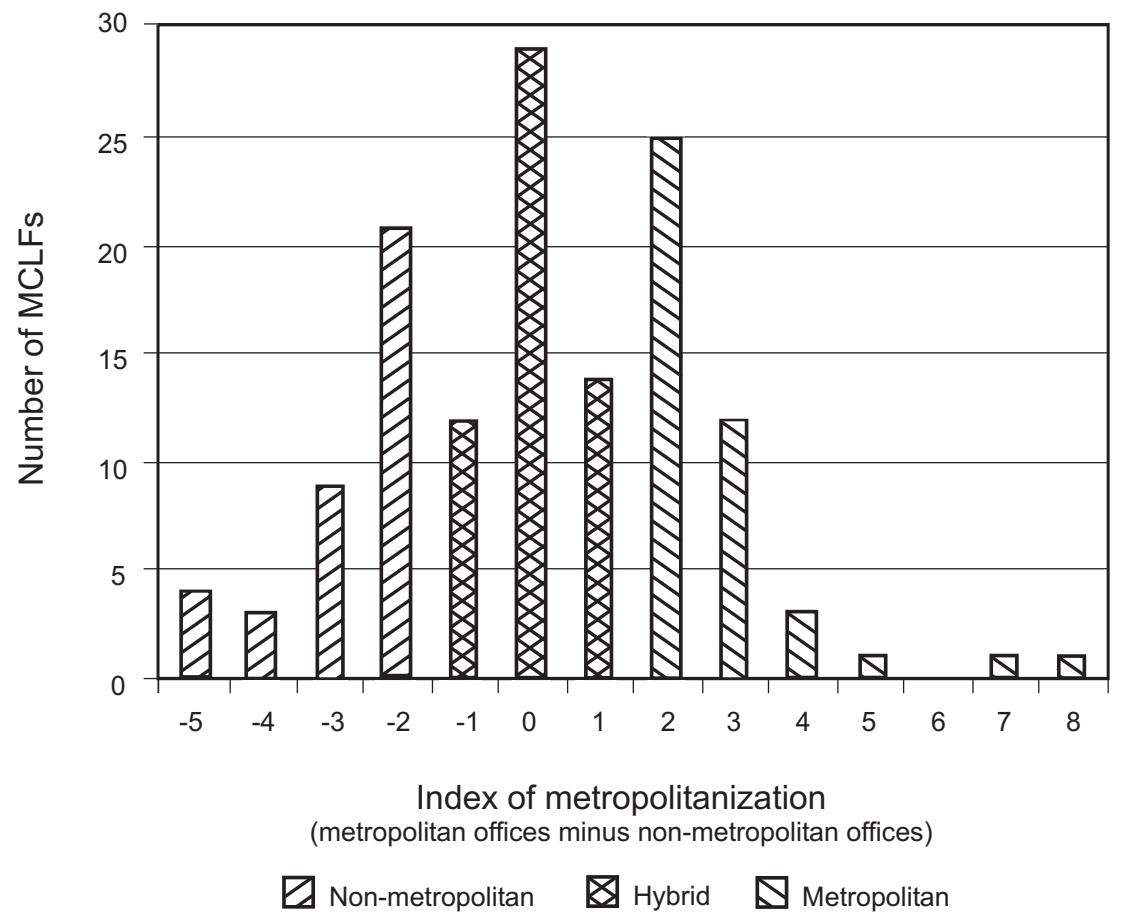


Figure 8 The Manchester polycentric mega-city region as practised by MCLFs

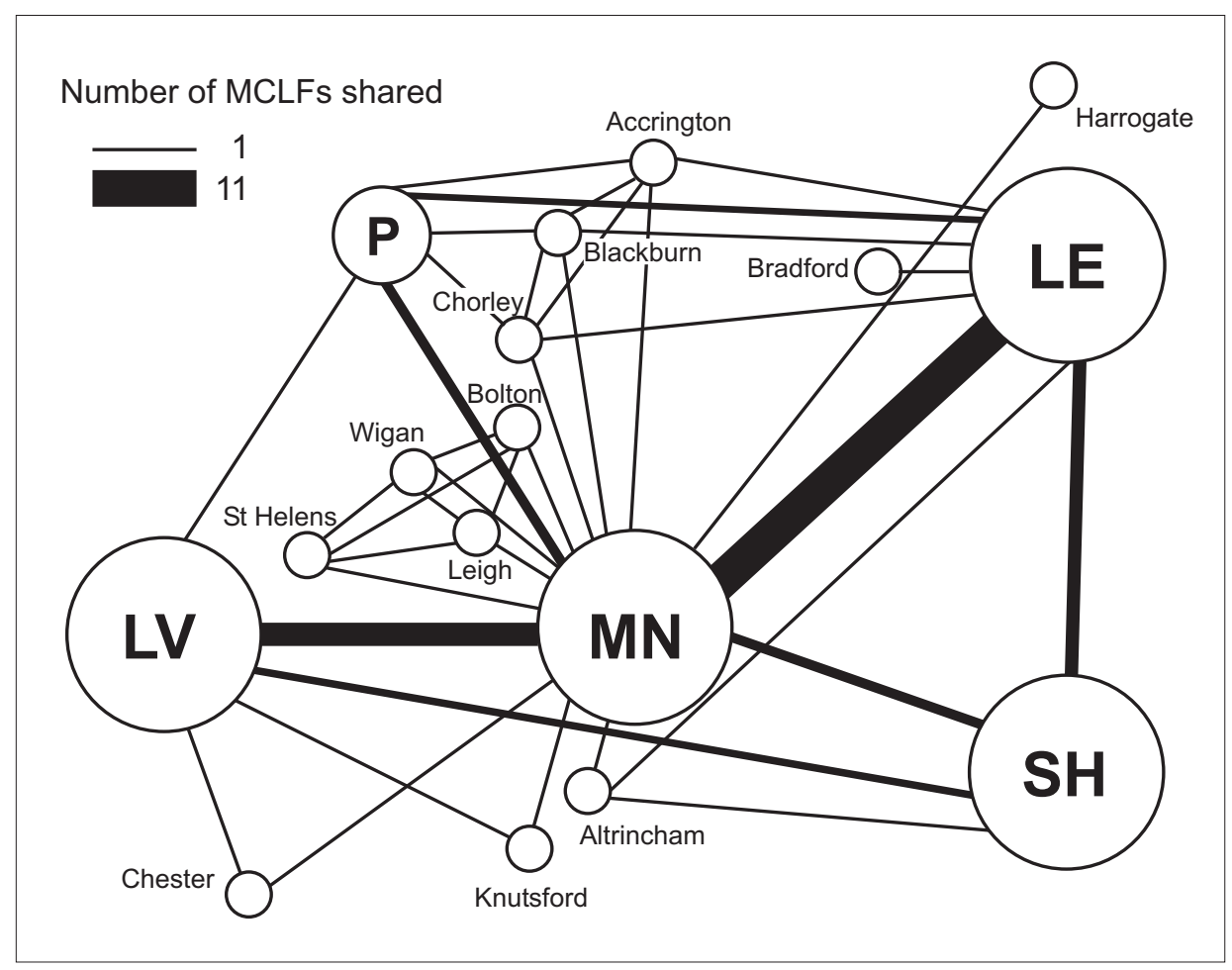

City codes see Figure 6 